\title{
Temporal Variation of Seedling Growth and Leaves Type of Four Morphotypes of Lannea Microcarpa Engl. \& K. Krause in Burkina Faso
}

\author{
Kadidia Semde, Msc-PhD Student \\ François Wennemi Kagambega, PhD \\ Hadou Haro, PhD \\ Souleymane Ganaba, PhD \\ INERA/DEF, Ouagadougou, Burkina Faso
}

Doi:10.19044/esj.2020.v16n21p364 URL:http://dx.doi.org/10.19044/esj.2020.v16n21p364

\begin{abstract}
This study evaluated the growth performance and the leaves type of seedlings from different morphotypes of Lannea microcarpa in the central plateau of Burkina Faso.Then, seeds of Lannea microcarpa were collected from four (4) morphotypes based on their botanical characters and noted as NLs: Lannea sp. from Naab-Mayooghin, MLs: from Mamousyorgo 1, MaLs: from Mamousyorgo2, ZLs: from Ziniaré. One hundred seeds per morphotypes were used for the seedlings production in nursery through sowing by using a randomized block design. The leaves type of the produced seedlings was investigated by visual observation. Significant differences in the growth traits of the seedlings were found among the four morphotypes $(p<0,05)$. The height and the collar diameter of the seedlings were found to be higher in NLs, MaLs and ZLs than those in MLs. Regarding the leaves, it was observed different types among the morphotypes. Seeds from NLs and MLs produced seedlings with both compound and simple leaves while those from ZLs and MaLs produced seedlings with only compound leaves. Generally, all morphotypes exhibited a relatively high growth with production of different types of leaves.
\end{abstract}

Keywords: Growth, Genetic Diversity, Disturbances, Plant Morphology, Burkina Faso

\section{Introduction}

In the Sahelian regions of Africa, natural resources have been under environmental factors and human-induced activities leading to a gradual degradation of forests and ecosystems (Ganaba et al. 2005 ; Houédjissin et al., 
2015). Indeed, the uncontrolled exploitation of tropical forests which abound in more than a half of the terrestrial plant species, along with consecutive droughts has resulted in a highly genetic resources loss (Belem et al., 2008; Atato et al., 2010; Haarmeyer et al., 2013). However, it is well known that natural resources conservation is essential for the sustainable development although scientific evidences are needed on plants biology and their growth performance for evidence-based decision-making purposes at national level. In the context of Burkina Faso, the vegetation has a wide ecological importance but it has been overexploited by the local communities to meet their socio-economic needs and this led to an ecosystem degradation and increased vulnability to the drought risks. Thus, recent studies showed that the disappearance of some isohyets as well as their appearance and descent to the south, in thirty years period, would be an indicator to a rapid drying of the climate (Ouédraogo, 2006). This contributed to an extinction of some woody plant species as reported by Ajiboye et al.,(2013) and particularly that of the species from the Lannea genus which were found to be endangered (Karen et $a l ., 2000)$. In order to face this situation, various studies were conducted on species of the Lannea genus but most investigations focused on the seeds germination process, the seed oil quality (Bazongo et al., 2014), as well as antioxidant and antibacterial properties of the plant organs (Ouattara et al., 2011; Yunus et al., 2013; Nwodo et al., 2015). Likewise, a recent study indicated the existence of variants belonging to Lannea microcarpa named "Lannea sp." or "Lannea microcarpa morphotypes" which showed some constraints in their natural regeneration with an aging state (Semdé, 2013). These morphotypes have been mainly found in the Central plateau region of the country and play major ecological and socio-economic roles. However, a key issue that is missing from the above previous studies, would be an explicit consideration of the plant growth dynamics which limit the natural regeneration of the species, especially for these described morphotypes. Therefore, this study aims to evaluate the growth performance and the leaves type of the seedlings produced from morphotypes of Lannea microcarpa in the central plateau of Burkina Faso in order to better understand the regeneration mechanisms. Thus, various aspects were considered as the plants growth potential and their leaves type.

\section{Material and methods}

\subsection{Study sites description}

Research activities were carried out in two sites located at Ziniare (12 $\left.{ }^{\circ} 35^{\prime} 01^{\prime \prime} \mathrm{N} 1^{\circ} 17^{\prime} 48^{\prime \prime} \mathrm{W}\right)$ and Zorgho (12 ' $\left.14^{\prime} 49^{\prime \prime} \mathrm{N} 0^{\circ} 36^{\prime} 55^{\prime \prime} \mathrm{W}\right)$ in the villages of Naab-Mayooghin and Mamousyorgo in which the seeds of the morphotypes were collected. Both sites are located in the Central Plateau region within the North Sudanuan phytogeographical zone of Burkina Faso. 
The increasing population (2.4\% annually) is mainly rural and nearly $80 \%$ of the population are farmers. Agriculture is the dominant land use surrounding the study sites. The climate is that of a typical Sudano-Sahelian zone with two distinct seasons: a dry season from October to May and a rainy season from June to September. The annual long-term rainfall for the region ranged from 701 to $900 \mathrm{~mm}$ over 120 to 140 days (Zoma, 2006). The rainfall is variable, both temporally and spatially. The mean annual potential for evapotranspiration exceeds $2000 \mathrm{~mm}$ per year.

The major soil types in the region are Lixisol, Cambisol, Vertisol and Lithosol. These soils are characterized by a low native soil fertility, low water holding capacity and soil surface crusting that do not allow water to easily infiltrate into the soil. Combined with the high rainfall intensities, this makes the soils very sensitive to erosion despite the gentle slope $(<3 \%)$. The vegetation found in the Northern and central part of this region is dominated by shrubland followed by woodland especially in Oubritenga province. However, the southern part of the region is mostly covered by woodlands along the rivers. The structure and function of the vegetation are strongly influenced by factors such as water and nutrient availability, fire and herbivory, which influence the trees height and density and the relative proportion of trees and grasses.

\subsubsection{Plant material}

The plant materials used in this experiment were seeds, collected from morphotypes of Lannea microcarpa. In Burkina Faso, eight species of the Lannea genus can be found including L. acida, L. barteri, L. fructicosa, Lannea edulis, L. egregia, L. kerstingii, L. velutina and L. microcarpa. However the studied morphotypes are plants presenting botanical features (simple leaves) which are different from previously described species of the Lannea genus.The fruits of the morphotypes are edible and looking alike those of the Lannea microcarpa (compound leaves). These plants are endangered by the local community activies.

\subsection{Seed collection and processing}

Seeds were collected in each site from four dominant trees of Lannea microcarpa's morphotypes having a well developed crown and abundant seeds, in June 2015. The collection was performed regarding some differences in the plant botanical characters and morphotypes were named accordingly as NLs, MLs, MaLs and ZLs (Lannea sp. from Naab-Mayooghin, Lannea sp. from Mamousyorgo 1, Lannea sp. from Mamousyorgo 2; Lannea sp. from Ziniaré, respectively). Seeds from morphotypes in farmlands were reaped directly from the trees at the time of natural dispersal and were brought to the laboratory for processing and germination tests. Physical damage on seeds was 
assessed by visual inspection and damaged seeds were discarded to ensure the use of fairly good quality seeds for the study. According to the National Tree Center in Ouagadougou, Burkina Faso, the seeds from our studied species do not need any pretreatment before germination.

\subsection{Germination and growth experiment}

The germination experiments were performed without pretreatment of the seeds. One hundred (100) seeds from each morphotype were considered and experiments were conducted at the plant nursery of Department Environment and Forest, Ouagadougou. The trial was performed using a randomized block design with four treatments (NLs, MLs, Mals and ZLs). Seeds from each morphotype were sown on a culture medium made of none sterile soils sampled in Ouagadougou (sand, dung and clay in the ratio 1:2:1 respectively). Polythene plastic pots (5 liters volume) were filled with the medium and kept moist. Two seeds were sown in each pot, making a total of 50 plastic pots per morphotypes (200 pots for all the trial) meaning that 50 replicates were used for each treatment (morphotype).This experiment was repeated twice in the nursery by using the same experimental conditions from july to december, 2015.To evaluate the plant growth patterns and their leaves type, the experiment was monitored daily for 100 days. For that, the germinated seeds were counted after the seedlings start to emerge from the culture medium. Tap water was used for daily watering except for the raining days. Two weeks after sowing, some seedlings in the plastic pots were removed to ensure that each pot contains only a single plant. No fertilizers or bacterial and/or mycorrhizal inoculation were used.

Starting from two weeks after seeds sowing, the number of leaves, the height and the basal diameter of the seedlings were recorded every two weeks during the experiment using a measuring tape and sliding caliper.

With regards to the leaves type determination, a visual observation was used since the first leaves appeared and a picture was taken for any observed change in the leaves type. Observation was repeated during the experiment.

\subsection{Data analysis}

All data from the experiment were analysed by applying an One-Way analysis of variance using XLSTAT software, version 2015. Data fulfilled the assumptions of normality and homogeneity test. Newman Keuls test was used to compare differences among treatment means. The significance level was set at $5 \%$. 


\section{Results}

\subsection{Growth performance of the morphotypes}

Figure 1 illustrates the temporal variation in seedlings height and stem diameter of the different morphotypes. The cumulative growth of these shoots exhibits three growing stages along with the experiment period (figure $1 \mathrm{a}$ and b). The first development stage extends from the first day to the $28^{\text {th }}$ day and a slow growth increment of the shoots was observed in all treatments. The second growth stage from the $28^{\text {th }}$ day to the $93^{\text {rd }}$ day showed epicotyl lenghtening with both high growth rate and plant leaves number . In this stage, young plants grew rapidly and shoots from the same treatment had clear leafy differentiation. The third stage begins from the $93^{\text {rd }}$ day in which the shoots growth became slow again.
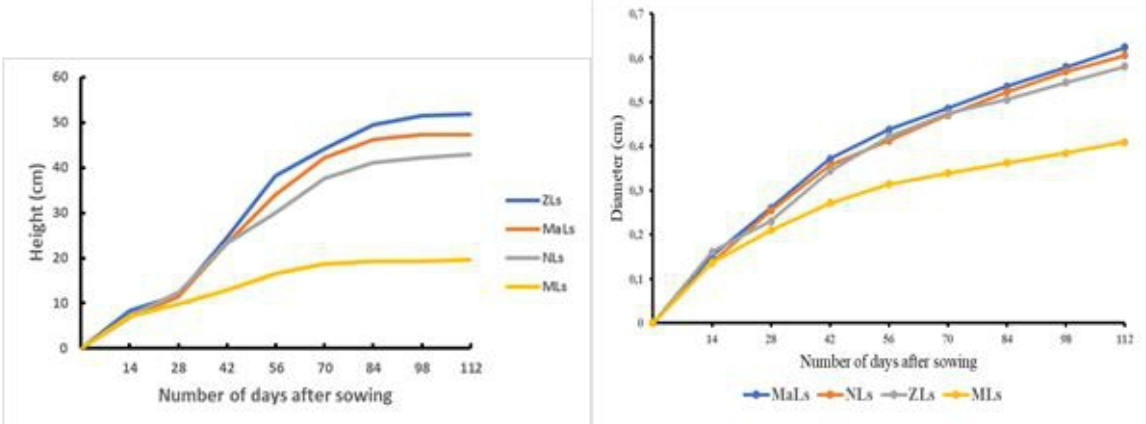

Figure 1: Growth in height (a) and diameter growth (b) of Lannea sp morphotypes. NLs: Lannea sp. from Naab-Mayooghin, MLs: Lannea sp. from Mamousyorgo 1, MaLs: Lannea sp. from Mamousyorgo 2; ZLs: Lannea sp. from Ziniaré

During the first growth stage, the results showed that growth rate of the shoots for all morphotypes was more or less regular. However, from the end of the first growth stage, comparison among morphotypes revealed significant differences in the temporal variation regarding the shoot height and stem diameter. Statistical analyses show that differences were mainly observed between the growth of MLs morphotype and that of the three others morphtypes (NLs, MaLs and ZLs). Despite the fact that no significant differences were found among NLs, MaLs and ZLs, the height and diameter increments were the highest in ZLs than in other treatments, followed by MaLs and the low value was recorded in MLs. At the end of the trial, the lowest values were obtained for MLs plants both in height and diameter growth (respectively figure $2 \mathrm{a}$ and $\mathrm{b}$ ) compared to other treatments. 

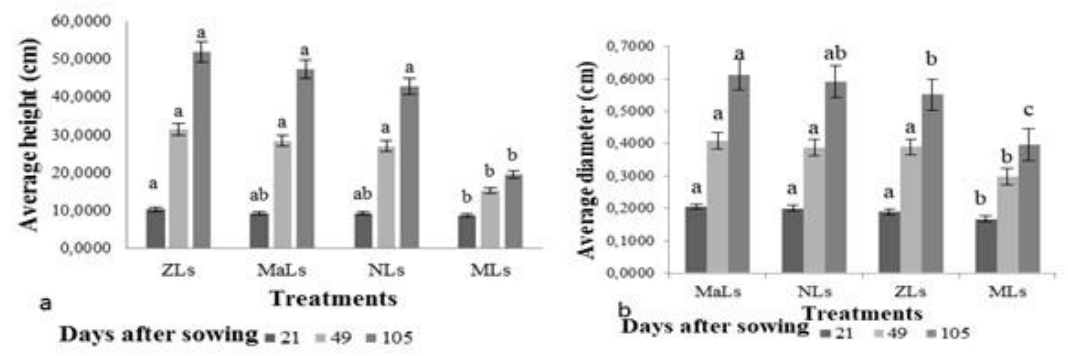

Figure 2: Timely change in shoots height (a) and diameter growth (b) for morphotypes of Lannea sp. (NLs: Lannea sp. from Naab-Mayooghin, MLs: Lannea sp. from Mamousyorgo

1, MaLs: Lannea sp. from Mamousyorgo2; ZLs: Lannea sp. from Ziniaré)

Treatments with the same letter above the bars indicate no significant differences according to the Newman-Keuls test $(p<0.05)$

\section{Determination of the leaves type}

The different stages of seedlings leaf development for the morphotypes are shown in figure 3. The results indicate a total of five steps: The first step corresponds to the appearance of the cotyledons (figure 3 a), the second, third and forth steps (as presented respectively in figure $3 \mathrm{~b}, \mathrm{c}$ and d) correspond to the appearance and development of the first leaf; finally, the fifth step reveals some differentiation on leaves type (figure 3 e and f).

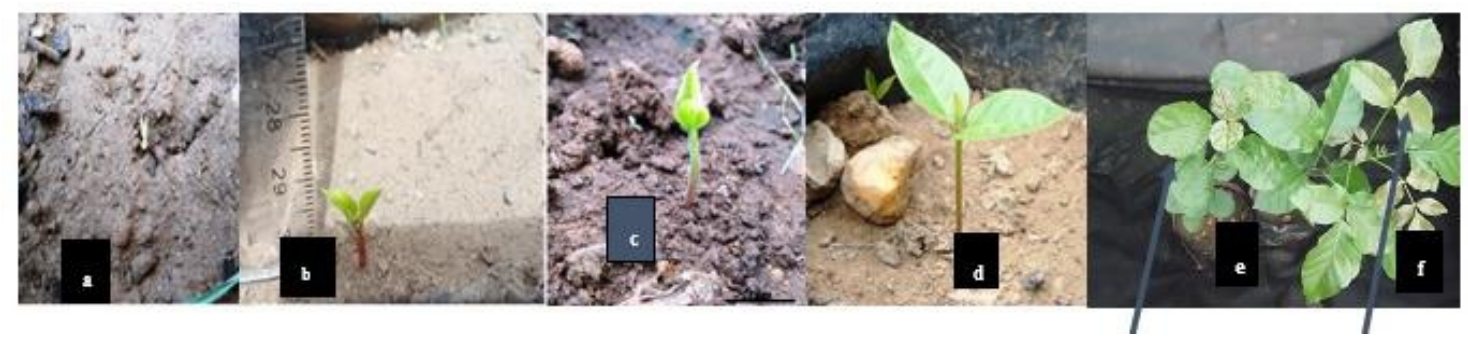

Simple leaves Compound leaves

Figure 3: Different leaves type of the morphotypes observed during the experiment (das= Days after sowing) $\mathrm{a}=5$ das, $\mathrm{b}=7$ das, $\mathrm{c}=10$ das, $\mathrm{d}=14$ das, $\mathrm{e}=21$ das, $\mathrm{f}=30$ das

Results indicate that seeds from he MaLs and ZLs morphotypes produced $100 \%$ of plants with compound leaves. However, by using the seeds from NLs and MLs morphotypes, plants with compound leaves and those with simple leaves were obtained in different proportions. This differentiation occurs from the $30^{\text {th }}$ day after sowing. The percentage of leaves type from the different Lannea sp morphotypes are shown in figure 4. 


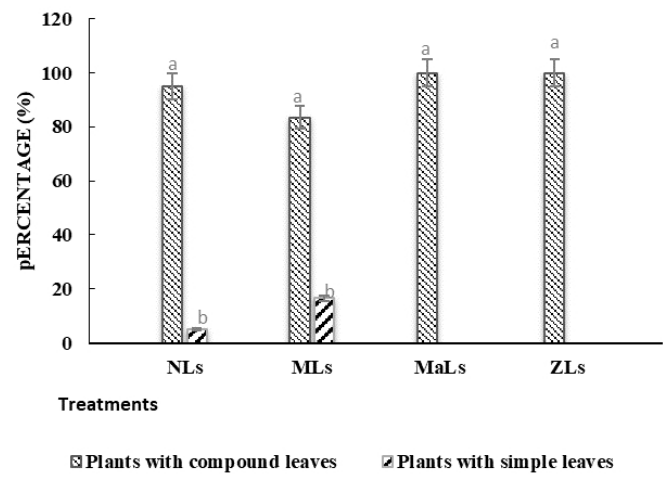

Figure 4: Percentage of plants regarding their leaves type among the morphotypes of Lannea sp. (NLs: Naab-Mayooghin; MLs: Mamousyorgo1; MaLs: Mamousyorgo2; ZLs: Ziniaré)

Treatments with the same letter above the bars indicate no significant difference according to the Newman-Keuls test $(p<0.05)$

\section{Discussion}

\subsection{Overall variation of the plant growth patterns}

In the present study, the seedling growth parameters and leaves type of the different Lannea sp morphtypes appeared to be relatively different. Indeed, except for MLs, the other morphotypes had a good growth potential regarding the stem height and diameter. The higher performance of the three morphotypes (Nls, MaLs and ZLs) could be explained by the fact that their individuals are more tolerant to environmental conditions. This is in line with other findings on others plants especially studies of Yélémou et al. (2007) on Piliostigma reticulatum and those of Rakotovololonalimanana et al. (2014) on Liquidambar styraciflua $\mathrm{L}$. These studies reported that the observed main growth difference among plants depends on their ability to adapt to environmental conditions. The lower performance for MLs as compared to the other treatments was suggested by literature evidence that it could be as a result of the plants low adaptation capacity to the local environmental conditions. Otherwise, the low growth patterns of MLs may also be related to a low seed quality (Semdé, 2013). Indeed, MLs is a most often attacked plant species by parasites which could affect the quality of its seeds. Similar observations were highlighted by Amani et al. (2016), Ghaffaripour et al. (2017) and Traoré and Jouquet (2020). Nevertheless, the observed differences in the growth patterns of the four morphotypes could not be linked only to the health status of their individuals but also the genetic variation which may arise from seeds. This might be further explained by the fact that plant growth and development are generally influenced by drought, temperature and other unfavorable factors that most often threaten the spread of the species (Ma et al., 2016; Sevillano et al., 2016; Rabiou et al., 2017). Three growth stages have been identified regarding the height and diameter temporal variation of 
the plants. During the first growth stage, the results showed that the growth rate of shoots for all morphotypes was more or less regular and low. The observed poor growth pattern at this stage may be explained by the long time needed for the burgeon formation at this moment. It is a period in which the sprouted seeds develop their root system primarily at the expense of their aerial organs development in order to adapt to environmental conditions. In the second growth stage, the higher growth rate of the seedlings and leaves production could be attributed to the nutrient utilization (water and substrates) as explained by Smolander et al. (2015). Our results corroborate with those obtained by Hamidou et al. (2014) on Sclerocarya birrea.

\subsubsection{Leaves type}

The observations made on the seedlings from the different morphotypes revealed a foliar differentiation. Indeed, seeds from the morphotypes NLs and MLs allow development of seedlings of which some have simple leaves and others with compound leaves while seedlings from MaLs and ZLs had only compound leaves. This foliar differentiation occurred in the first week of the second month after sowing. However, our results were different from those reported by Sacandé (2007) and those by Agbogan (2014) who focused on the direct sowing of Lannea microcarpa seeds and found that all grown plants had compound leaves. As described by Lardat (1989) and Arbonnier (2009), the type of compound leaves characterizes the species of the genus Lannea. Then, these plants with simple leaves were not previously found among the Lannea microcarpa species and even within the Lannea genus. Thus, seeds from MaLs and ZLs morphotypes which produced seedlings with compound leaves exclusively were very similar to Lannea microcarpa. However, regarding the seeds from NLs and MLs, it produced seedlings with both simples and compound leaves and this could be attributed to a genetic variation and/or mutation. Indeed, the observed difference on leaves type among plants from the morphotypes could be attributed to a chromosomal mutation or crossed pollination between L. microcarpa and another species of the Lannea genus. This latter consideration could indicate that the studied morphotypes and L. microcarpa are genetically close. Furthermore, the difference could be also attributed to a hybridization since $L$. microcarpa would be a cross-pollinated plant with a reduced viability and fruitfulness. This is in agreement with the findings of Guilmette (2006) in which it was highlighted that the cross-pollinated plants reproducing by sexual way have always heterogenous offsprings. According to Martin (1996), environmental disturbances would also be responsible for natural plant groups heterogeneity. However, the low percentage of plants with simple leaves could indicate the difficulty of Lannea sp to regenerate through direct seeding or sexual regeneration (by seeds). 


\section{Conclusion}

This study showed that the four morphotypes had several differences in their growth traits. The growth preformance of NLs, MaLs and ZLs was higher (height and collar diameter) than that of MLs. However, all the four morphotypes had a relatively good growth potential in nursery. The study also revealed two leaves types within the Lannea morphotypes. Seeds collected from NLs and MLs produced both seedlings with compound and simple leaves. Those with compound leaves had similar leaves type compared to those of Lannea microcarpa. Other complementary studies are needed in order to confirm whether the studied morphotypes of Lannea sp. and Lannea microcarpa can crossbreed.

\section{References:}

1. Ajiboye, T.O, Raji, H.O, Muritala H, F., Ojewuyi, O.B, YakubuM, T. (2013). Anthocyaninextract of Lannea microcarpa fruits stall oxidativer out associated with aflatoxin B1 hepatocarcinogenesis ;

Food Biosciences, http://dx.doi.org/10.1016/j.fbio.2013.09.0024, 5 867

2. Amani, A., Inoussa, M.M, Guimbo, I., Mahamane, A., Saadou, M., \& Lykke, A.M. (2015). Germination et croissance de quatre espèces de Combretaceae en pépinière. Tropicultura, 33,2,135145

3. Amusan, O.O.G., Sukati, N.A, Dlamini, P.S. and Sibandze F.G. (2007). Some Swazi phytomedicines and their constituents. African Journal of Biotechnology Vol. 6 (3) pp. 267-272, Available online at http://www.academicjournals.org/AJB ISSN 1684-5315

4. Arbonnier, M. (2009). Arbres, arbustes et lianes des zones sèches d'Afrique de l'Ouest CIRAD, Centre de coopération internationale en recherche agronomique pour le développement; MNHN, Muséum national d'histoire naturelle ; UICN, Union mondiale pour la nature, $141 \mathrm{p}$.

5. Atato, A., Batawila, K. et Akpagana, K. (2010). Etude sur les espèces ligneuses alimentaires utilisées pendant la période de soudure au Togo. Rapport d'étude sur les espèces ligneuses alimentaires. Université de Lomé, Togo, 25p.

6. Bazongo, P., Bassolé, I.H.N, Nielsen, S., Hilou, A., Dicko, M.H. and Vijai, K. S. (2014). Characteristics, Composition and Oxidative Stability of Lannea microcarpa Seed and Seed Oil. Molecules 2014, 19, 2684-2693; doi:10.3390/molecules19022684, ISSN 1420-3049

7. Belem, B., Olsen, C.S, Theilade, I., Bellefontaine, R., Guinko, S., Lykke, A.M., Diallo, A., Betti, J.L. (2001). Vulnérabilité des plantes utilisées comme antipaludiques dans l'arrondissement de Mintom au sud de la réserve de biosphère du Dja (Cameroun) publié par National 
Botanic Garden of Belguim. Systematic and geography of plants, 71 (2): 661 - 678.

8. Ganaba, S., Ouadba, J.M. et Ouetian, B. (2005). Exploitation traditionnelle des végétaux spontanés en région sahélienne du Burkina Faso. Vertigo, revue électronique en sciences de l'environnement 6 (2) $: 15$.

9. Ghaffaripour, S.B, Nina, V., Samson, R. (2017). The importance of seed reserve on performance and breeding of tamarind seedlings, Scientia Horticulturae, 222; 145-152, ttp://dx.doi.org/10.1016/j.scienta.2017.04.032

10. Guilmette, M. (2006). Impact d'une pollinisation assistée sur la Production fruitière du sambucus nigra. Mémoire département de phytologie faculté des sciences de l'agriculture université Laval Québec ssp. canadensis (1.) r. bolli ; 119p

11. Haarmeyer. D.H., Schumann, K., Römermann, M.B, Rüdiger, W., Thiombiano, A., Hahn, K. (2013). Human impact on population structure and fruit production of the socio-economically important tree Lannea microcarpa in Burkina Faso; Agroforest Syst 87:1363-1375

12. Hamidou, A., Boube, M., Mahamane, L., Ali, M., Mahamane, S. and Bellefontaine, R. (2015). Uses and preferences of woody species in two protected forests of Dan Kada Dodo and Dan 12 DOI: 10.5897/JHF2014.0374, ISSN 2006-9782

13. Houédjissin, S.S., Dangou, S.J., Azokpota, P., Cacaï, G., Agbidinoukoun, A. (2015). Régénération in vitro de l'arbre à suif (pentadesmabutyraceasabine), une espèce ligneuse à usages multiples (lum) vulnérable au bénin. European Scientific Journal July vol.11, No.21 ISSN: $1857-7881$

14. Karen H, Thiombiano A. (2000). Perception des espèces en voie de disparition en milieu gourmantché (Est du Burkina Faso). Berichte des Sonderforschungsbereichs 268, Band 14, Frankfurt: 285-297.

15. Lardat, I. (1989). Contribution à l'étude du genre Lannea (Anacardiaceae) du Burkina Faso. Mémoire de DEA. Institut des Sciences de la Nature, Institut de Développement Rural. Laboratoire de Botanique. Université de Ouagadougou, 103p.

16. Ma, Y., Zhang, J., Li, X., Zhang, S., Lan, H. (2016). Effects of environmental stress on seed germination and seedling growth of Salsola ferganica (Chenopodiaceae). Science Direct Acta Ecologica Sinica 36: 456-463

17. Martin, A. (1996). Germination et dispersion des graines chez Glaucium flavum crantz (papaveraceae). Acta Botanica Malacitana, 21: $71-78$ 
18. Nwodo, N.J, Ibezim, A., Ntie-Kang, F., Adikwu, M.U. and Mbah, C.J. (2015). Anti Trypanosomal Activity of Nigerian Plants and Their Constituents. Molecules, 20, 7750-7771; doi:10.3390/ molecules 20057750 ? ISSN 1420-3049

19. Ouattara, L., Koudou, J., Zongo, C., Barro, N., Savadogo, A., Bassolé, I.H.N., Ouattara, A.S. and Ttaoré A.S. (2011). Antioxydant and antibacterial activity of three species of Lannea from Burkina Faso. Journal of applied sciences, 11 (1) 157-162, ISSN : 1812-5654

20. Ouédraogo, A. (2006). Diversité et dynamique de la végétation ligneuse de la partie orientale du Burkina Faso. Thèse de Doctorat, Unité de Formation en Science de la Vie et de la Terre, Laboratoire de Biologie et Ecologie Végétales, Université de Ouagadougou, Burkina Faso; 230p.

21. 21. Rabiou, H., Tougiani, A., Guimbo, I., Issaharou-Matchi, I., Weber, J.C., Dadé, H., Katkoré B, Moussa, B. and Mahamane, A. (2017). Dynamic plantations: intraspecific variability in growth of five varieties of Ziziphus mauritiana (pomme du sahel) and development trajectories in the sahelian region of niger. International journal of current engineering sciences. vol. 6, issue, 06, pp. 128-135. ISSN: 2320- 9046

22. Rakotovololonalimanana, H., Rakotondraoelina, H., Chaix G, Ramamonjisoa L, Thevenon MF, Randrianjafy H, Ramananantoandro $\mathrm{T}$ (2014). Adaptation et variabilité génétique de la croissance de Liquidambar styraciflua L. de l'essai de provenances à Mandraka, Madagascar. Bois e t forêts des tropiques $\mathrm{n}^{\circ} 320$ (2)

23. Sacandé, M. (2007). Lannea microcarpa Engl.Seed Leaflet, Forest \& Landscape Denmark • HørsholmKongevej 11DK-2970 Hørsholm

24. Semdé, K. (2013). Caractérisation botaniques et ethnobotanique des individus de Lannea sp. dans la commune urbaine de Zorgho (Burkina Faso). Mémoire de Master 2, Université de Ouaga 1, Professeur Joseph KI ZERBO, 71p.

25. Sevillano, I., Short, I., Grant, J., O’Reilly, C. (2016). Effects of light availability on morphology, growth and biomass allocation of Fagus sylvatica and Quercus robur seedlings. Forest Ecology and Management (374) 11-19p

26. Smolander, A., Saarsalmi, A., Tamminen, P. (2015). Response of soil nutrient content, organic matter characteristics and growth of pine and spruce seedlings to logging residues. Forest Ecology and Management ttp://dx.doi.org/10.1016/j.foreco.2015.07.019, 357 117-125

27. Traore S, Jouquet P. 2020. Seedlings of Three Savanna Woody Species in Pots as Feedback to the Soil of Macrotermes Subhyalinus Mound. 
European Scientific Journal.16 (3) ISSN: 1857 - 7881 (Print) e - ISSN 1857- 7431 Doi:10.19044/esj.2020.v16n3p1

28. Yélémou, B., Yaméogo, G., Millogo, R.M., Hien, V. (2007). Germination sexuée et dynamique de développement de Piliostigmareticulatum(D.C.) Hochst, une espèce agroforestière du Burkina Faso. Article scientifique 18 (3) : 185-192.

29. Yunus, M.M., Zuru, A.A., Faruq, U.Z., Aliero, A.A. (2013). Assessment of Physicochemical Properties of Biodiesel from African Grapes (Lannea microcarpa Engl.\&K.Krause) Nigerian Journal of Basic and Applied Science, 21 (2): 127-130 DOI: http://dx.doi.org/10.4314/njbas.v21i2.7

30. Zoma, L.R. (2009). Monographie de la région du plateau central. Ministère de l'économie et des finances, comité national du recensement, bureau central du recensement, Burkina Faso, 174p. 